\title{
STUDY FENOMENOLOGI PERSEPSI REMAJA TENTANG HIV/AIDS DI SMK YPE SLAWI KABUPATEN TEGAL
}

\author{
Evi Zulfiana ${ }^{1} J_{u h r o t u n ~ N i s a}{ }^{2}$ \\ 1 evi.zulfiana33@gmail.com. ${ }^{2}$ nisa.jn20@gmail.com \\ ${ }^{1,2)}$ Program Studi D III Kebidanan Politeknik Harapan Bersama \\ Jl.Mataram no.09 Pesurungan Lor Kota Tegal
}

\begin{abstract}
Abstrak
Permasalahan pada remaja terutama pada HIV/AIDS menyangkut pengetahuan yang tidak lengkap dan tidak tepat tentang HIVIAIDS. sebagian besar pemahaman salah terkait HIV/AIDS. Dari data dinas kesehatan kabupaten Tegal tahun 2017 jumlah penderita HIV sebanyak 421 kasus, sedangkan penderita AIDS sebanyak 291 kasus. Kasus HIV pada remaja sebanyak 25 kasus dan kasus AIDS pada remaja sebanyak 3 kasus. Penelitian ini bertujuan untuk mengetahui persepsi remaja tentang HIV/AIDS di SMK YPE Slawi. Sampel yang diambil secara purposive sampling, Sampel pada penelitian ini adalah informan utama siswa (1 orang) dan siswi (2 orang) kelas XII. Sedangkan informan triangulasi dalam penelitian ini adalah guru BK (1 orang). Penelitian ini bersifat kualitatif dengan menggunakan metode deskriptif.Pengumpulan data dilakukan dengan teknik wawancara mendalam sesuai dengan pedoman wawancara. Hasil penelitian Dari 3 jawaban informan utama sebagian besar dapat menjawab dengan benar akan tetapi pada pertanyaan cara penularan dan pencegahan HIV/AIDS dari ketiga informan tidak dapat menjawab dengan benar dikarenakan hasil pernyataan dari ketiga informan belum pernah ada yang sosialisai mengenai pengetahuan HIV/AIDS. Dari jawaban informan triangulasipun menyatakan belum pernah ada yang sosialisasi tentang HIV/AIDS. Upaya dari sekolah untuk mencegah HIV AIDS dengan cara bekrja sama dengan dinas kesehatan untuk mengadakan sosialisasi khususnya tentang HIV/AIDS.
\end{abstract}

Kata Kunci : persepsi, pengetahuan HIV/AIDS

\begin{abstract}
Problems in adolescents, especially in HIV / AIDS, involve incomplete and inappropriate knowledge about HIV / AIDS. most of the wrong understanding is related to HIV / AIDS. From the data from the Tegal district health office in 2017 there were 421 cases of HIV sufferers, while there were 291 AIDS cases. HIV cases in adolescents were 25 cases and AIDS cases in adolescents as many as 3 cases. This study aims to determine the perceptions of adolescents about HIV / AIDS in YPE Slawi Vocational School. Samples taken by purposive sampling, the sample in this study were the main informants of students (1 person) and students ( 2 people) class XII. While triangulation informants in this study were $B K$ teachers (1 person). This research is qualitative by using descriptive methods. Data collection is done by in-depth interview techniques in accordance with interview guidelines. The results of the 3 main informants' answers were mostly able to answer correctly but on the question of how to spread and prevent HIV / AIDS from the three informants could not answer correctly because of the statements from the three informants there had never been a socialization regarding knowledge of HIV I AIDS. From the answers of the triangulation informants stated that there had never been any socialization about HIV / AIDS. Efforts from the school to prevent HIV AIDS by working together with the health office to conduct socialization especially on HIV / AIDS.
\end{abstract}

Keywords: perception, knowledge of HIV / AIDS 


\section{Pendahuluan}

Remaja atau adolescence (Inggris), berasal dari bahasa Latin "adolescere" yang berarti tumbuh kematangan social dan psikologi. Masa remaja adalah di tandai adanya perubahan fisik, emosi, dan psikis. Masa remaja yakni antara usia 1019 tahun adalah suatu periode masa pematangan organ reproduksi manusia dan sering disebut masa pubertas ${ }^{[1]}$.

Salah satu yang paling rawan menyangkut masalah kesehatan bagi remaja adalah kesehatan reproduksi. Masa remaja merupakan masa dimana organ reproduksi mulai berfungsi. Pematangan organ reproduksi di barengi oleh perkembangan social dan emosi yang mendorong remaja untuk melakukan halhal sebagai proses pencarian identitas diri. Pada masa ini, resiko tertular penyakit reproduksi sangat tinggi. Oleh karena itu, di perlukan upaya untuk mencegah remaja terjangkit penyakit reproduksi. Permasalahan pada remaja terutama pada HIV/AIDS menyangkut pengetahuan yang tidak lengkap dan tidak tepat tentang HIV/AIDS. sebagian besar remaja belum mengetahui secara menyeluruh soal penyakit mematikan ini. Bahkan di antara mereka menganggap, HIV sebagai penyakit yang tak berbahaya. Lebih parah lagi, banyak sekali pemahaman salah terkait HIV/AIDS ${ }^{[2]}$.

HIV adalah yaitu virus yang melemahkan system kekebalan tubuh.AIDS adalah kumpulan gejala penyakit akibat menurunnya kekebalan tubuh yang sifatnya di peroleh (bukanbawaan). HIV berkembang dari infeksi menjadi suatu penyakit yang mengancam jiwa manusia, yaitu acquired Immune Deficiency Syndrom (AIDS) $)^{[3]}$.

Dari data dinas kesehatan kabupaten Tegal tahun 2017 jumlah penderita HIV sebanyak 421 kasus, sedangkan penderita AIDS sebanyak 291 kasus. Kasus HIV pada remaja sebanyak 25 kasus dan kasus AIDS pada remaja sebanyak 3 kasus ${ }^{[4]}$.

Berdasarkan studi awal menunjukkan bahwa remaja di SMK YPE Slawi Kabupaten Tegal dari 10 siswa 7 diantaranya belum mengerti tentang HIV/AIDS ${ }^{[5]}$.

\section{Metode Penelitian}

Penelitian ini bersifat kualitatif. Dengan menggunakan metode deskriptif, sampel diambil secara purposive sampling.

Sampel pada penelitian ini adalah siswa (1 orang ) dan siswi (2 orang ) kelas XII yang bersedia menjadi responden yang merupakan informan utama. Sedangkan informan triangulasi dalam penelitian ini adalah guru BK (1 orang $)^{[6]}$.

Dalam penelitian ini perlakuan peneliti berupa wawancara mendalam sesuai dengan pedoman wawancara. Hasil wawancara direkam dan dibuat catatan lapangan.

\section{Hasil Dan Pembahasan}

a. Persepsi remaja tentang pengetahuan HIV/AIDS [7]

1) Pengertian HIV/AIDS

Berdasarkan wawancara 3 informan utama mempunyai jawaban yang sama mengenai persepsi remaja tentang pengertian HIV yaitu sejenis virus yang menyerang system kekebalan tubuh manusia sedangkan AIDS adalah kumpulan gejala yang disebabkan HIV.

" kalau menurut saya HIV merupakan virus yang menyerang imun manusia, kalau AIDS kondisi yang timbul akibat HIV itu menurut saya" (Informan pertama).

" HIV menurut saya adalah kekebalan tubuhnya menurun yang diakibatkan oleh virus sedangkan 
AIDS adalah penyakit yang diakibatkan karena kekebalan menurun" (informan kedua).

" menurut saya kalau HIV itu virus yang melemahkan kekebalan tubuh tapi kalau AIDS itu akibat yang ditimbukan dari HIV begitu menurut saya" (informan 3)

Virus HIV akan masuk dalam sel darah putih dan merusaknya, sehingga sel darah putih yang berfungsi sebagai pertahanan terhadap infeksi akan menurun jumlahnya. Akibatnya system kekebalan tubuh menjadi lemah dan penderita mudah berbagai terkena penyakit. Jawaban informan tentang AIDS menjawab berbeda kalimat tapi intinya sama. Sedangkan pengertian AIDS singkatan dari Acquired Immunodeficiency Syndrom, yaitu kumpulan gejala penyakit (sindrom) yang dapat akibat turunnya kekebalan tubuh yang disebabkan oleh HIV

2) Persepsi remaja tentang penyebab HIV/AIDS

Persepsi remaja tentang penyebab HIV/AIDS dari 3 informan mengatakan jawaban yang sama bahwa penyebab HIV/AIDS adalah virus.

" kalau penyebab dari HIVI AIDS menurut saya karena virus" (Informan I).

" penyebab dari HIV/ AIDS sudah pasti karena virus" (Informan 2)

"HIV?AIDS itu disebabkan
karena virus,
saya"(Informan 3)

Virus HIV akan masuk dalam sel darah putih dan merusaknya, sehingga sel darah putih yang berfungsi sebagai pertahanan terhadap infeksi akan menurun jumlahnya. Akibatnya system kekebalan tubuh menjadi lemah dan penderita mudah berbagai terkena penyakit. Aids disebabkan oleh virus yang mempunyai beberapa nama yaitu HTL II, LAV, RAV. Yang nama ilmiayahnya di sebut Human Immunodeficiency Virus (HIV) yang berupa agen viral yang dikenal dengan retrovirus yang ditularkan oleh darah dan punya afinitas yang kuat terhadap limfosit $\mathrm{T}$.

3) Persepsi remaja tentang cara penularan HIV

Persepsi remaja tentang cara penularan HIV/AIDS dari 3 informan mengatakan :

" menurut saya cara penularan HIV lewat keringat karena keringat itukan dikeluarkan oleh tubuh jadi sudah pasti akan menular" (Informan I).

" Penularan HIV itu bisa melalui makan dalam satu tempat karena biasanya kalau makan dalam satu tempat akan menular virusnya seperti itu"(Informan 2).

" kalau menurut saya cara penularan HIV bisa lewat ciuman, biasanyakan kalau orang ciuman tidak ada air ludahnya, nah dari air ludah itu dapat menularkan HIV"(Informan 3).

Dari jawaban informan mengenai persepsi remaja tentang cara penularan HIV /AIDS adalah semua informan belum bisa menjawab sesuai, hal ini menunjukan bahwa pengetahuan informan masih kurang.

Menurut Kusmiran (2011: 131) Terdapat 3 cara penularan HIV, yaitu :

a) Melalui hubungan seksual Hubungan seksual merupakan 
jalur utama penularan HIV/AIDS yang paling umum ditemukan. Virus dapat ditularkan dari seseorang yang sudah terkena HIV kepada mitra seksualnya (pria ke wanita, wanita ke pria, pria ke pria) melalui hubungan seksual tanpa pengaman (kondom).

b) Parental (produk darah)

Penularan yang dapat terjadi melalui transfuse darah, atau penggunaan alat-alat yang sudah dikotori darah seperti jarum suntik, jarum tato, tindik dan sebagainya.

c) Perinatal

Penularan melalui ibu kepada anaknya. Ini bisa terjadi pada saat anak masih berada dalam kandungan, ketika dalam proses lahir atau sesudah lahir. Kemungkinan ibu pengidap HIV melahirkan bagi HIV positif adalah 15\%-39\%. Seorang bayi yang baru lahir akan membawa antibody ibunya, begitupun kemungkinan positif dan negatifnya si bayi tertular HIV adalah tergantung dari seberapa parah tahapan perkembangan AIDS pada diri sang ibu. Sebaiknya tes darah sebelum hamil.

Kelompok yang beresiko terkena HIV adalah :

a) Wanita dan laki-laki yang selalu berganti-ganti pasangan dalam melakukan hubungan seksual.

b) Wanita dan laki-laki pekerja seks.

c) Melakukan hubungan seksual yang tidak wajar seperti melalui anal dan mulut, homoseksual dan biseksual.

d) Penyalahgunaan obat-obatan melalui suntikan secara bergantian.

4) Persepsi remaja tentang pencegahan HIV

Persepsi remaja tentang pencegahan HIV/AIDS dari 3 informan mengatakan bahwa :

" menurut saya cara pencegahannya harus menjaga agar tidak bersenggolan dengan orang yang terkena HIV "(Informan I).

" pencegahannya ya jangan makan dalam satu tempat makan agar tidak tertular penyakit HIV" (Informan 2).

"kalau menurut saya pencegahan HIV itu jangan melakukan ciuman karena dapat menular"(Informan 3).

Pencegahan penularan HIV/AIDS pada dasarna sama dengan pencegahan PMS:

a) Melakukan hubungan seksual hanya dengan satu pasangan yang setia atau menghindari hubungan seksual dengan yang berganti-ganti.

b) Mempunyai perilaku seksual yang bertanggung jawab dan setia pada pasangan.

c) Setiap darah transfuse di cek terhadap HIV dan donor darah kepada sanak saudara lebih sehat dan aman dibanding donor darah profesional.

d) Menghindari injeksi, periksa dalam, prosedur pembedahan yang tidak baik steril dari petugas kesehatan yang tidak bertanggungjawab.

Menggunakan kondom dengan hati-hati, benar dan konsisten 
Prinsip pencegahan HIV/AIDS dikenal dengan a, b, c, d yaitu :

a) Abstinence : tidak berhubungan seksual

b) Be faithful : saling setia dengan satu pasangan

c) Condom : selalu menggunakan kondom saat melakukan hubugan seksual

d) Drug : tidak mengguakan obatobatan terlarang

b. Sosialisai dari pihak dinas kesehatan

Hasil wawancara responden menyatakan bahwa :

" kalau sosialisasi masalah HIV/AIDS dari dinas kesehatan sepertinya belum ada" (Informan I)

" dari dinas kesehatan belum pernah datang kesekolahan ini untuk sosialisasi masalah HIV/AIDS"(Informan 2)

" kalau ga salah dari dinas kesehatan belum pernah ada yang kesini menjelaskan tentang HIV/AIDS, soalnya saya ga pernah dapet sosialisasi dari dinas kesehatan"(Informan 3)

" dari dinas kesehatan memang belum pernah ada yang memberikan sosialisasi khusunya tentang HIV/AIDS mungkin kalau ada yang sosialisasi dari dinas kesehatan terkait pengetahuan HIV/AIDS siswa siswi kami akan lebih tau tentang HIV/AIDS" (Informan Triangulasi)

Upaya penanggulangan HIVAIDS merupakan suatu program upaya teknis dalam rangka mengendalikan pengendalian penyebaran HIV/AIDS di sector kesehatan. Program ini sangat didukung oleh pemerintah . peraturan daerah nomor 2 tahun 2013 tentang penanggulangan HIV/AIDS. Kewajiban pemerintah daerah hususnya dinas kesehatan melakukan penanggulangan seperti melakukan sosialisasi dan melakukan pengobatan bagi orang dengan oranh HIV/AIDS, akan tetapi hasil wawancara dari informan utama dan informan triangulasi belum pernah ada dari dinas kesahatan melakukan sosialisai di SMK YPE ${ }^{[8]}$

c. Upaya pihak sekolah untuk mencegah HIV/AIDS

" Kalau upaya dari sekolah untuk mencegah HIV/AIDS kami akan berencana untuk melakukan kerjasama dengan dinas kesehatan untuk melakukan sosialisasi agar siswa siswi kami pengetahuan lebih bagus khususnya tentang HIV/AIDS “ (Informan Triangulasi)

Sesuai amanat Undang-Undang Nomor 36 Tahun 2009 tentang Kesehatan dan Undang-Undang Nomor 40 Tahun 2004 tentang Sistem Jaminan Sosial Nasional (SJSN) serta Undang Undang Nomor 23 Tahun 2014 tentang Pemerintahan Daerah ditetapkan bahwa kesejahteraan merupakan urusan pemerintahan yang didaerahkan. Sementara itu, Penyakit menular masih menjadi masalah kesehatan masyarakat yang menimbulkan kesakitan, kematian dan kecacatan yang tinggi sehingga perlu dilakukan upaya pencegahan, pengendalian dan pemberantasan yang efektif dan efisien, secara komperehensif berkesinambungan sejak tingkat fasilitas pelayanan kesehatan primer (puskesmas). sebagai penanggung jawab kesehatan wilayah setempat berkewajiban melaksanakan upaya kesehatan masyarakat (UKM) essensial berupa promosi kesehatan atau penyuluhan peningkatan pengetahuan komprehensif masyarakat tentang pencegahan penularan HIVAIDS dan IMS serta pencegahan dan 
pengendalian penyakit menular melalui deteksi atau penemuan dini HIV/AIDS dan IMS. Dengan demikian pemerintah daerah kabupaten/kota dan provinsi memiliki peran dan tanggung jawab penting untuk pelaksanaan operasionalnya sebagai standar pelayanan minimal kesehatan dasar masyarakat.

\section{Kesimpulan}

Dari 3 jawaban informan utama sebagian besar dapat menjawab pertanyaan pengetahuan HIV AIDS dengan benar akan tetapi pada pertanyaan cara penularan dan pencegahan HIV/AIDS dari ketiga informan tidak dapat menjawab dengan benar dikarenakan hasil pernyataan dari ketiga informan belum pernah ada yang sosialisai mengenai pengetahuan HIV/AIDS dan tidak ada mata pelajaran yang membahas tentang HIV/AIDS.

jawaban informan triangulasi menyatakan bahwa memang belum pernah ada dari institusi manapun yang melakukan sosialisasi tentang HIV/AIDS di SMK YPE Slawi dan belum menerapkan mata pelajaran tentang HIV/AIDS.

Upaya dari sekolah untuk mencegah HIV AIDS dengan cara bekrja sama dengan dinas kesehatan untuk mengadakan sosialisasi khususnya tentang HIV/AIDS

\section{Daftar Pustaka}

[1]. Widyastuti. Kesehatan Reproduksi. Yogyakarta: Fitra Maya, 2009.

[2]. Mintarjo, Sri. Waspadai IMS di Kalangan Remaja. Jakarta: Sunda Kelapa Pustaka. 2007.

[3]. Kusmiran, Eni. Kesehatan Reproduksi Remaja dan Wanita. Jakarta: Salemba Medika, 2011.
[4]. Depkes RI. Profil Kesehatan Indonesia Tahun 2013. Jakarta: Depkes RI, 2013.

[5]. Moleong, Lexy J. Metodologi Penelitian Kualitatif. Bandung: PT Remaja Rosdakarya, 2013.

[6]. Nurachmah, E. Faktor Pencegahan HIV/AIDS akibat perilaku Beresiko Tertular Pada Siswa SLTP. Jurnal Makara Kesehatan. 2009. 13(2):63-68.

[7]. Soerjono Soekanto. Sosiologi Keluarga Tentang Ikhwal Keluarga, Remaja dan Anak. Jakarta : Rineka Cipta, 2004. 